\title{
Dual quality and its influence on consumer behaviour according to the income
}

\author{
Lucia Bartkova $^{1, *}$, and Mária Sirotiaková ${ }^{1}$ \\ ${ }^{1}$ University of Matej Bel, Faculty of Economics, Institute of Managerial Systems in Poprad, \\ Francisciho 910/8, 05801 Poprad, Slovakia
}

\begin{abstract}
.
Research background: Dual quality occurred in natural way after fall of Communism. Global producers from Western countries had to adapt formulas and composition of their products to living standards in countries of former soviet bloc.

Purpose of the article: But present situation is different, living standards equalize, people travel, they purposely buy abroad, and they discover that international goods known from home shops have different attributes composition, colour, aroma or density of product - in the same or very similar package in foreign countries. In Slovak Republic, there was missing a research of consumers' opinions in context of dual quality as global problem.

Methods: We conducted such research by questionnaire method on the sample of 987 Slovak respondents. Because dual quality is connected to many goods and besides different attributes also price is different many times, we were interested how is this problem perceived by consumers with different income. We divided respondents in our research into three groups according to the monthly income of household: low, middle and high income.

Findings \& Value added: According to the results, consumers with high income perceive problem of dual quality more, they are more interested to be informed about this problem and they are also more willing to share their own experiences with dual quality. On the other side, consumers with low income more changed their consumer behaviour due to information about dual quality. This article brings results of unique research and brings proposals for improving of the situation about dual quality in Slovakia with respect to incomes of consumers.
\end{abstract}

Keywords: dual quality; consumer behaviour; social class; income

JEL Classification: $Q 18 ; M 38 ; M 31$

\footnotetext{
*Corresponding author: lucia.bartkova@umb.sk
} 


\section{Introduction}

Sooner or later, everyone becomes a consumer. Everyone uses consumer products to meet their needs and wants. Consumer behaviour is a very broad and complex process in which a person buys and consumes a certain product for his needs. Many factors influence a person's consumer behaviour, one of them is belonging to a social class. Social classes, resp. layers are relatively homogeneous and society hierarchically dividing groups, where class members share similar values, interests, and behaviours [1]. Social classes have several characteristics. People in each group tend to behave similarly and differently from people from a different social class. People in social classes hold some roles and statuses [2]. Social layers differ in clothing, manner of speech, entertainment preferences, and many other characteristics. Social classes can be set by various characteristics as income, occupation, education etc. [3]. We choose an income of household as a determinant of analysis of consumer behaviour in particular social class in context of dual quality for our research.

Belonging to a social class influences the preference of products and brands, social classes show different preferences when choosing products in many areas, including clothing, furniture, entertainment, cars, electronics, etc. Higher social classes with higher income read and travel more, devote themselves to culture and individual sports, while lower classes with lower income, watch more television, spend more time shopping, take care of households and prefer collective sports [4]. Social classes also differ in media preferences, with upper-class consumers preferring magazines and books, while lower-class consumers often prefer television. The lower classes are generally less interested in politics than the upper classes [5]. Upper social classes tend to use the Internet more - compared to lower classes [6], but on the other hand, lower social classes use more social networks than higher classes [7].

It is legitimate to adapt products, also in terms of composition and quality, to different cultures, subcultures and social classes, based on specific customs and preferences. However, these adjustments should be identified and properly communicated to the target group so as to avoid confusion and misunderstandings in the markets.

Cases with dual quality of goods began to be noticed by people in Slovakia immediately after the fall of communism [8]. People from the countries of the former Soviet Union considered the inhabitants of the countries of Western Europe as a reference group, they wanted to buy the same products as them, products that had long been unavailable or banned in Eastern Europe. Western products gradually began to penetrate the eastern markets as well. With the opening of the borders, the inhabitants of Eastern and Central Europe began to travel abroad, where they also bought products of brands they knew from home, and there were cases when they blundered on dual quality [9]. The consumers of countries in the Eastern part of the EU complain that quality of some products is lower in their country than quality of the same brands and the same producer is abroad [10].

At first, they began to notice it in the cosmetics and drugstores to which they were used at home, and the products bought abroad had a different consistency, intensity and duration of smell, in the case of washing powders also composition. Gradually, the inhabitants of Slovakia, especially those living in the west of the country near the border with Austria, noticed the existing problems in the food assortment, e.g. for drinks, coffee or fish fingers, when the composition of these foods of the same brand and with the same or very similar packaging, purchased in Slovakia was different than in other EU countries [11]. At present, up to $16 \%$ of Slovak consumers say that they go shopping abroad for a specific purpose, with the reason being more and more the higher quality of goods abroad [12].

Residents living in central or eastern Slovakia, further from the borders with the west, gradually gained experience with dual-quality goods. The economic situation in these 
regions forced people to work abroad, and these people began to import some products from abroad in better quality and became important influencers in this area.

There were carried out several tests confirming dual quality from various countries of EU [13], but their methodology was incomparable. Based on a report by the Joint Research Centre (JRC) on the results of EU product testing, the European Commission has begun to prepare unify testing methodology and steps to eliminate dual quality in the EU, including labelling of products and fines for businesses. At present, within the EU, products should be safe in the first place, their composition is not comparable in individual countries. According to the European Commission, products may have different compositions in different countries if manufacturers state this in the composition on the product. It is therefore not a legislative problem, but an ethical problem, because if consumers buy the same product in different places, they assume that it is the same.

The issue of dual food quality has three levels. The first level is product safety. Food safety is considered a public good, as any form of inadequate management could cause severe harm to all participants in the supply chain, significantly affecting public health [14]. Manufacturers also argue in this area, claiming that there are certain rules and regulations for the production of products, given nationally or internationally, and they do not violate these rules. The fact that the composition of these products is different for some countries does not matter, in principle, because the products are still safe, made from raw materials that are allowed in that country. If different raw materials are allowed in different countries, manufacturers will adapt to this regulation and choose the most advantageous option for them. At the same time, manufacturers say that they state all the information on the packaging, thus also complying with all regulations.

With regard to food safety, there is a Rapid Alert System (RAS) in the EU, which enforces a law focusing on, for example, the presence of foreign objects in food or the concentration of food supplements [15]. A 2017 study on a sample of 1,446 samples showed that most of the contaminated foods registered in the RAS system came from Eastern Europe [16]. The feeling of consumers in Central and Eastern Europe that they are a 'rubbish bin' is therefore partly justified. The relationship between food safety and quality subsequently influences consumer behaviour and demand [17-19], with the recent demand for healthy and high-quality food [20].

The second level of discussion about the dual quality of products concerns their composition, i.e. that the customer always knows exactly what he is buying in the store. Traceability is also an important principle, which means that the consumer must be able to trace back where the product comes from. From this point of view, there are no uniform rules from which ingredients products are to be made, it is important that it contains only ingredients approved for the European market and that the customer is informed what the product is made of [21]. This gives manufacturers the opportunity to modify the recipe of their products so that local raw materials can be used, which may be specific and different from raw materials in other countries, respectively they can choose a more economical alternative that is allowed in the country. Such behaviour of manufacturers is completely legitimate - the problem arises when products with different compositions are packaged in identical packaging. We do not see problem in such products with different composition being visibly marked on the packaging with the symbol "Made for ..." or "Made in ... (e.g. Slovakia)". Moreover, according to the research, around $45 \%$ of people searched for the country of origin [22]. We believe that such a label will even positively influence the behaviour of those consumers who are conservative, traditionalist and prefer local goods in an effort to support the domestic economy.

The third level of discussion about the dual quality of goods is based on sensory assessment. This is a subjective evaluation of the product according to taste or smell. The EU does not regulate this area. It is here that manufacturers have the space to adapt their 
products to the local preferences of national consumers. However, this does not mean that it is okay to promote these tailor-made products in the same, uniform packaging. On the contrary, we think that, as in the previous case, the marking of the product with the symbol e.g. "Slovak recipe" or "Slovak taste" will have a positive impact on consumer behaviour. The costs and effort of such a step are minimal, while at the same time producers would avoid the problem of dual quality and accusations of "earning" money from Central and Eastern European consumers.

However, in addition to legislation and ethics, dual quality has another dimension for consumers, and that is the economic dimension [23]. As several tests showed, goods purchased in Western European countries not only had a healthier composition, they were still cheaper in the same package at the same weight (or were at the same price but with a higher weight). In addition, the people of Central and Eastern Europe have lower incomes than those in Western Europe, and such information only encourages consumers in Central and Eastern Europe to feel that their position in the EU's single market is not fair. However, it should be emphasized that price comparison was mostly not the primary objective of testing and its methodology was not comparable, therefore this conclusion cannot be generalized.

\section{Methods}

Belonging to a social class influences customers' consumer behaviour. Consumers from different social classes buy different products and focus on different criteria when shopping. We analysed the consumer behaviour of respondents in terms of their belonging to the social class according to their monthly income of household in the context of dual quality. The research involved 919 respondents, and the sample was representative due to their age.

We divided the respondents into groups according to the monthly income of the household: the first group consisted of respondents with the lower income of $€ 400-1,000$, second group consisted of respondents with middle income of $€ 1,001-1,600$ and third group of respondents with higher income of over $€ 1,601$. The aim of the research was to find out whether there are differences in the perception of the issue of dual quality by consumers according to their affiliation to the income of household and to formulate recommendations for practice on this basis.

\section{Results and Discussion}

We started the study by finding out what criterion is most important for consumers when making a purchase decision. According to research, while for consumers with the lower and middle income the most important criterion is the price of goods, for the consumers with higher income it is more quality than price. As can be seen from Table 1, the highestincome respondents heard about the problem of dual quality to a greater extent than others and also said that this problem is important for them. We assume that the higher the consumer's income, the more he cares about buying quality products, and the more sensitive he is to what he gets for his money. If he buys e.g. one of the most expensive drinks in the offer of the world-famous brand, and subsequently finds that despite the high price and the well-known menu of the brand he received a lower quality than the consumer in another country, he naturally minds it. 
Table 1. Awareness of dual quality and its importance for respondents by income in $\%$

\begin{tabular}{|l|c|c|}
\hline Income & $\begin{array}{c}\text { Have you heard of the dual quality } \\
\text { problem? }\end{array}$ & $\begin{array}{c}\text { Do you consider this problem } \\
\text { important for your life? }\end{array}$ \\
\hline Lower & 88 & 72 \\
\hline Middle & 89 & 75 \\
\hline Higher & 93 & 81 \\
\hline
\end{tabular}

Table 2 shows in which goods respondents consider the problem of dual quality to be the most important, depending on their income. For consumers with lower and middle income, the problem of dual quality is most serious in food and detergents. These are basic goods that they buy for the household, so they have the highest priority for them. In the group with lower income, we still see a penchant for clothing. We estimate that this is because at a low income, the consumer does not buy clothes very often and at the same time hopes that his clothes will last as long as possible.

Table 2. Goods for which respondents consider the problem of dual quality to be the most important, by income in $\%$

\begin{tabular}{|l|c|c|c|c|c|}
\hline Income & Foodstuffs & Soft drinks & Cosmetics & Detergents & Clothing \\
\hline Lower & 80 & 7 & 18 & 26 & 10 \\
\hline Middle & 84 & 6 & 22 & 24 & 5 \\
\hline Higher & 78 & 12 & 27 & 21 & 18 \\
\hline
\end{tabular}

At a group of consumers with higher income, we see that they prefer cosmetics at the expense of food, and we also see an increase in the importance of clothing. We assume that this is due to the fact that they buy them at higher prices from more prestigious brands and thus expect from them a quality corresponding to a higher price. At the same time, we see that in addition to food, detergents are also more important for the consumer with lower income, which confirms the recognition that the lower social classes devote more time to household care.

Table 3 shows that interest in being informed about dual quality is growing with consumer income. This is natural, as they travel more, come into contact with such products, are more interested in this problem and consider it important. They are willing to invest in buying more money, so they expect reasonable value for their money. At the same time, members of the group with higher income are more willing to inform others about the cases they have identified than consumers with lower income.

Table 3. Respondents' interest in informing about dual quality by income in $\%$

\begin{tabular}{|l|c|c|}
\hline Income & $\begin{array}{c}\text { Are you interested in being informed } \\
\text { about cases of dual quality of goods? }\end{array}$ & $\begin{array}{c}\text { Are you willing to inform other } \\
\text { consumers about cases of dual } \\
\text { quality goods? }\end{array}$ \\
\hline Lower & 89 & 83 \\
\hline Middle & 90 & 81 \\
\hline Higher & 94 & 85 \\
\hline
\end{tabular}


In the analysis of information sources on dual quality, which respondents prefer depending on the income, we see from Table 4 that with increasing income, interest in providing information through a specialized website and through the Ministry of Agriculture decreases, while interest in information from the Slovak Trade Inspection decreases. The lower interest of the consumers with lower and middle income in the information provided through the Ministry of Agriculture is most likely due to the fact that the lower social classes are generally less interested in politics than the upper classes.

Table 4. Preference of sources of information on dual quality by respondents by income in $\%$

\begin{tabular}{|c|c|c|c|c|c|c|c|}
\hline હ્ & 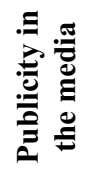 & 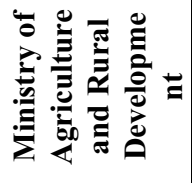 & 兽 & 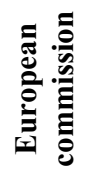 & $\frac{0}{0}$ & 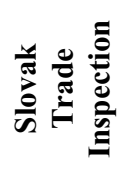 & 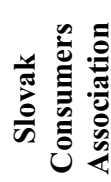 \\
\hline Lower & 47 & 16 & 6 & 11 & 15 & 23 & 8 \\
\hline Middle & 46 & 20 & 7 & 16 & 21 & 18 & 5 \\
\hline Higher & 48 & 22 & 5 & 15 & 23 & 17 & 5 \\
\hline
\end{tabular}

On the topic of information sources, we were interested in how the respondents perceive the credibility of individual information sources. From Table 5 we see that with declining income, confidence in the results of scientific research in the context of dual quality decreases, but at the same time, confidence in the media increases.

Table 5. Credibility of sources of information on dual quality for respondents by income in\%

\begin{tabular}{|l|c|c|c|c|c|c|}
\hline Income & $\begin{array}{c}\text { Own } \\
\text { experience }\end{array}$ & Family & $\begin{array}{c}\text { Relatives, } \\
\text { friends }\end{array}$ & Community & Media & $\begin{array}{c}\text { Scientific } \\
\text { research }\end{array}$ \\
\hline Lower & 79 & 46 & 38 & 10 & 30 & 28 \\
\hline Middle & 78 & 48 & 35 & 9 & 22 & 41 \\
\hline Higher & 79 & 47 & 42 & 7 & 20 & 41 \\
\hline
\end{tabular}

This finding also corresponds with the perception of consumer behaviour of members of different social classes, according to which members of lower classes with lower income more often watch radio and television, and conversely, members of higher classes with higher income prefer reading books and magazines, where there is more room for a broader and more professional explanation of the problem of dual quality.

Table 6 shows which way of sharing information concerning their own findings of dual quality is preferred by the respondents according to their income. Here too, as in examining the preferred sources of information on this issue, interest in using the website is growing with increasing revenue (Table 4 and Table 6). This is in line with the recognition that consumers with higher income tend to use the Internet more compared to consumers with higher income. As in the first case, the interest in the Slovak Trade Inspection is declining when the method of sharing information with other consumers with growing income is preferred. 
Table 6. Method of informing other consumers preferred by respondents in $\%$

\begin{tabular}{|l|c|c|c|c|c|}
\hline Income & Website & $\begin{array}{c}\text { Slovak Trade } \\
\text { Inspection }\end{array}$ & $\begin{array}{c}\text { Slovak } \\
\text { Consumers } \\
\text { Association }\end{array}$ & $\begin{array}{c}\text { Mobile } \\
\text { application }\end{array}$ & $\begin{array}{c}\text { Social } \\
\text { networks }\end{array}$ \\
\hline Lower & 29 & 23 & 8 & 13 & 23 \\
\hline Middle & 37 & 14 & 4 & 14 & 21 \\
\hline Higher & 39 & 13 & 5 & 16 & 19 \\
\hline
\end{tabular}

On the other hand, as Table 6 shows, interest in using social networks to share one's own experience of dual quality is growing with declining income. This also confirms the previous knowledge that social networks are used more by lower social classes than higher classes.

At the same time, our research shows that all respondents changed their consumer behaviour under the influence of dual quality information in terms of greater control over the composition and design of goods, regardless of social affiliation.

\section{Conclusion}

Research into the impact of dual quality on consumer behaviour in terms of consumer affiliation with income has confirmed several actual findings, but has also provided some new information. People with growing incomes have more personal experience with dual quality goods, and at the same time this issue is more important to them. While consumers with higher income consider this problem to be serious for products expressing their status (cosmetics, clothing), consumers with lower income consider it to be serious for household products (food, detergents and cleaning products).

With increasing income, there is a growing interest in information on dual quality (especially at the professional and scientific level) as well as a willingness to share personal experience of this problem with other consumers. With increasing income, the preference of the Internet as a source of information grows, on the contrary, the interest in information provided by Slovak Trade Inspection decreases.

In the past, a specialized transnational website was to be set up, where countries would share their information on dual quality, which was to be managed by the Slovak Republic. As the European Joint Centre has confirmed dual quality in the EU and the European Commission has developed a uniform methodology for examining goods in the context of dual quality, such a transnational website is losing its relevance. Nevertheless, consumers are interested in being informed about dual quality and would welcome it as a source of information via the Internet. As one of the most trustworthy institutions for Slovak consumers is the Slovak Trade Inspection, we propose that for the purpose of sharing information on dual quality, its own website should be used, resp. we propose to create a specialized website set up for this purpose under the auspices of Slovak Trade Inspection.

However, it should be noted that the Slovak Trade Inspection site itself in its current form is not satisfactory. When visiting this website, the potential complainant will immediately encounter a problem. In the section Submission of suggestions, complaints, proposals and requests, he can read that Slovak Trade Inspection is not authorized to solve:

- submissions and inquiries concerning the quality and health safety of food, agricultural and tobacco products or unfair commercial practices in their sale (the competent supervisory authority is the State Veterinary and Food Administration and its regional components), 
- submissions and inquiries concerning the health safety and safety of food, raw materials and beverages in mass caterers (the competent supervisory authority is the Public Health Office and its regional units);

- submissions and inquiries concerning cosmetic products are handled by the Public Health Office and its regional components (the Public Health Office is the supervisory body for cosmetic products).

Such a procedure is considerably complicated when one institution refers the consumer to other institutions depending on the type of product to which the dual quality relates. In addition, Slovak Trade Inspection, as a place for reporting cases of double quality, is particularly preferred by consumers with higher income, where there is a presumption of lower education, and such a procedure can be quite complicated for them and can discourage them from doing so.

A separate section could be set up within the Slovak Trade Inspection for the purpose of reporting cases of double quality. This step would include a separate internet channel on the Slovak Trade Inspection website and responsible persons who would further address the issue of double quality. On the one hand, they could forward a complaint to the responsible authority, on the other hand, they would keep a record of these complaints. The complainant could be redirected to this site from the Slovak Trade Inspection site or could visit it directly. This would make it easier for consumers to share experience with dual quality in line with their preferences, and provide competent authorities with a clear database of cases to work with. However, consumer information should not be made public until it has been verified by the competent authorities and the manufacturer has been given the opportunity to comment.

Based on the results of the survey, we can state that all respondents consider the best solution for double quality to be the labelling of products of different quality with different packaging and different prices, regardless of social class and income. We therefore propose that goods which, for objective reasons, are adapted to the taste preferences of individual countries, should be properly labelled. For the Slovak Republic we propose e.g. the inscription "Made in ... (Slovakia)" or "Made for ... (Slovakia). Another designation can be "... (Slovak) recipe" or the title "Slovak" above the main product name. This label evokes a sense of authenticity in the consumer and encourages conservative and traditionalist consumers to buy. When using local raw materials (or raw materials allowed in a given country), if they differ in the purchase price or simplify the processing process, this fact should also be taken into account in the selling price of the goods.

This contribution was supported by the project No. 1/0757/18, "Consumer behaviour in buying goods of daily consumption with an emphasis placed different contents of goods offered on markets of selected EU countries".

\section{References}

1. Kotler, P., Keller, K. L. (2013). Marketing management. Praha: Grada Publishing.

2. Šramková, M. (2019). Zátažové situácie v praxi manažéra. Banská Bystrica: Belianum.

3. Shavitt, S. Jiang, D. Cho, H. (2016). Stratification and segmentation: Social class in consumer behaviour. Journal of consumer psychology, 26(4), 583-593.

4. Táborecká-Petrovičová, J. (2011). Modely spotrebitel'ského správania sociálnych tried pri tvorbe marketingovej stratégie. Bratislava: Iura Edition.

5. Laurison, D. (2016). Social Class and Political Engagement. Sociology Compass, $10(8), 684-697$. 
6. Saeed, A. (2016). The Relationship Between Internet Usage, Socioeconomic Status, Subjective Health and Social Status. Business \& Economic Review, 2016(8), 67-82.

7. Yates, S. J., Lockley, E. (2018). Social Media and Social Class. American Behavioral Scientist, 62(9), 1291-1316.

8. Čimová, D. (2017, March 17). Na Slovensku sme výrobkom ponechali názvy, ale charakter sme im zmenili. Dennik N. Retrieved from: https://e.dennikn.sk/707216/naslovensku-sme-vyrobkom-ponechali-nazvy-ale-charakter-sme-im-zmenili/

9. Ichijo, A., Ranta, R. (2016). Food, National Identity and Nationalism: From Everyday to Global Politics. Hampshire: Palgrave Macmillan.

10. Klabusayova, N. (2018). Consumer in the European Union and Dual Food Quality. In M. Stanickova, L. Melecky, E. Kovarova \& K. Dvorokova (Eds.), Procedings of the $4 T H$ international conference on European integration (pp. 712-719). Ostrava: Technical University of Ostrava.

11. European Commission. (2019, June 24). Dual Food Quality: Commission releases study assessing differences in the composition of EU food products. European Commission. Retrieved from: https://europa.eu/rapid/press-release_IP-19-3332_en.htm

12. GfK. (2015, August 17). Pri výbere obchodného ret’azca je najdôležitejšia čerstvost', odhalil prieskum. Stratégie. Retrieved from: https://strategie.hnonline.sk/tlacovespravy/785816-pri-vybere-obchodneho-retazca-je-najdolezitejsia-cerstvost-odhalilprieskum

13. Sisto, R., Pellegrini, G., La Sala, P. (2019). Dual quality food: A negative social externality or a competitiveness opportunity? Agricultural Economics -Zemedelska Ekonomika, 65(7), 307-313.

14. Hernandez-Rubio, J., Perez-Mesa, J. C., Piedra-Munoz, L. Galdeano-Gomez, E. (2018). Determinants of Food Safety Level in Fruit and Vegetable Wholesalers' Supply Chain: Evidence from Spain and France. International Journal of Environmental Research and public Health, 15(10), 2246.

15. Czepielewska, E., Makarewicz-Wujec., M, Różewski, F., Wojtasik, E., KozłowskaWojciechowska, M. (2018). Drug adulteration of food supplements: A threat to public health in the European Union? Regulatory Toxicology and Pharmacology, 97(8), 98102.

16. Djekic, I., Jankovic, D., Rajkovic, A. (2017). Analysis of foreign bodies present in European food using data from Rapid Alert System for Food and Feed (RASFF). Food Control, 79(9), 143-149.

17. Grunert, K. G. (2005). Food quality and safety: consumer perception and demand. European Review of Agricultural Economics, 32(3), 369-391.

18. Zweitering, M. H. (2015). Risk assessment and risk management for safe foods: Assessment needs inclusion of variability and uncertainty, management needs discrete decisions. International Journal of Food Microbiology, 213(11), 118-123.

19. Fernández-Ferrín, P. (2018). The valuation and purchase of food products that combine local, regional and traditional features: The influence of consumer ethnocentrism. Food Quality and Preference, 64(3), 138-147.

20. Kamrath, C. (2019). Is food involvement in purchasing decisions always low? A consumer study from Germany. PharmaNutrition, 14, 100157.

21. euractiv.sk (2019, August 7). Problém s rozdielnym zložením potravín existuje, no nehovori nič o ich kvalite. Euractiv. Retrieved from: 
https:/euractiv.sk/section/ekonomika-a-euro/news/problem-s-rozdielnym-zlozenimpotravin-existuje-no-nehovori-nic-o-ich-kvalite/

22. Petrescu-Mag, R. M., Petrescu, D. C. (2017) Product policy - food quality labeling as food patriotism. Insights on consumer label reading behavior. QualityAccess to Success, 18, 327-333.

23. Bartková, L. (2019). How do consumers perceive the dual quality of goods and its economic aspects in the European Union? An empirical study. Problems and Perspectives in Management, 17(3), 382-394. 